Weed Technology

www.cambridge.org/wet

\section{Research Article}

Cite this article: Asher BS, Dotray PA, Liebl RA, Keeling JW, Ritchie GD, Udeigwe TK, Reed JD, Keller KE, Bowe SJ, Aldridge RB, Simon A (2021) Vertical mobility and cotton tolerance to trifludimoxazin, a new protoporphyrinogen oxidase-inhibiting herbicide, in three West Texas soils. Weed Technol. 35: 144-148. doi: $10.1017 /$ wet.2020.95

Received: 9 June 2020

Revised: 4 August 2020

Accepted: 19 August 2020

First published online: 25 August 2020

\section{Associate Editor:}

David Johnson, Corteva Agriscience

\section{Keywords:}

Cotton tolerance; Palmer amaranth; preemergence; preplant; protoporphyrinogen oxidase; vertical mobility; West Texas soils

\section{Nomenclature:}

flumioxazin; saflufenacil; trifludimoxazin; cotton; Gossypium hirsutum L

\section{Author for correspondence:}

B. Scott Asher, Global Herbicide Marketing, Product Development, BASF Corporation, Research Triangle Park, NC 27882.

(Email: scott.asher@basf.com)

\title{
Vertical mobility and cotton tolerance to trifludimoxazin, a new protoporphyrinogen oxidase-inhibiting herbicide, in three West Texas soils
}

\author{
B. Scott Asher ${ }^{1}$ (1) Peter A. Dotray ${ }^{2}$ (1), Rex A. Liebl ${ }^{1}$, J. Wayne Keeling ${ }^{3}$, \\ Glen D. Ritchie ${ }^{4}$, Theophilus K. Udeigwe ${ }^{5}$, Jacob D. Reed ${ }^{6}$, Kyle E. Keller ${ }^{7}$, \\ Steve J. Bowe ${ }^{7}$, Ryan B. Aldridge ${ }^{7}$ and Anja Simon ${ }^{8}$

\begin{abstract}
${ }^{1}$ Global Herbicide Marketing, Product Development, BASF Corporation, Research Triangle Park, NC, USA; ${ }^{2}$ Rockwell Professor and Extension Weed Specialist, Department of Plant and Soils Science, Texas Tech University, Lubbock, TX, USA; ${ }^{3}$ Professor, Texas A\&M AgriLife Research and Extension Center, Lubbock, TX, USA; ${ }^{4}$ Associate Professor of Crop Physiology, Texas Tech University, Lubbock, TX, USA; ${ }^{5}$ Assistant Professor of Soil Chemistry, Texas Tech University, Lubbock, TX, USA; ${ }^{6}$ Field Biology Representative, BASF Corporation, Lubbock, TX, USA; ${ }^{7}$ Biology Project Manager, Herbicides; Biology Group Leader, Herbicides; Biology Laboratory Technician; BASF Corporation, Research Triangle Park, NC, USA and ${ }^{8}$ Global Biology Development, Herbicides, BASF Corporation, Limburgerhof, Germany
\end{abstract}

\begin{abstract}
Trifludimoxazin, a new protoporphyrinogen oxidase-inhibiting herbicide, is being evaluated for possible use as a soil-residual active herbicide treatment in cotton for control of small-seeded annual broadleaf weeds. Laboratory and greenhouse studies were conducted to compare vertical mobility and cotton tolerance of trifludimoxazin to flumioxazin and saflufenacil, which are two currently registered protoporphyrinogen oxidase-inhibiting herbicides for use in cotton, in three West Texas soils. Vertical soil mobility of trifludimoxazin was similar to flumioxazin in Acuff loam and Olton loam soils, but was more mobile than flumioxazin in the Amarillo loamy sand soil. The depth of trifludimoxazin movement after a $2.5-\mathrm{cm}$ irrigation event ranged from 2.5 to $5.0 \mathrm{~cm}$ in all soils, which would not allow for crop selectivity based on herbicide placement, because ideal cotton seeding depth is from 0.6 to $2.54 \mathrm{~cm}$ deep. Greenhouse studies indicated that PRE treatments were more injurious than the $14 \mathrm{~d}$ preplant treatment when summarized across soils for the three herbicides ( $43 \%$ and $14 \%$ injury, respectively). No differences in visual cotton response or dry weight was observed after trifludimoxazin preplant as compared with the nontreated control within each of the three West Texas soils and was similar to the flumioxazin preplant across soils. On the basis of these results, a use pattern for trifludimoxazin in cotton may be established with the use of a more than 14-d preplant restriction before cotton planting.
\end{abstract}

(c) The Author(s), 2020. Published by Cambridge University Press on behalf of Weed Science Society of America. This is an Open Access article, distributed under the terms of the Creative Commons Attribution licence (http:// creativecommons.org/licenses/by/4.0/), which permits unrestricted re-use, distribution, and reproduction in any medium, provided the original work is properly cited.

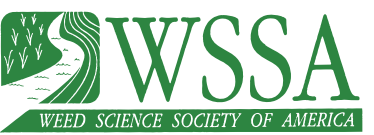

\section{Introduction}

The integration of soil-residual herbicides in glyphosate-resistant crops is a common recommendation to improve consistency of weed management systems (Bond et al. 2011; Norsworthy et al. 2012). Research has shown that programs containing a soil-residual herbicide in glyphosate-resistant cotton maximizes weed control and lint yield (Burke et al. 2005; Clewis et al. 2008; Culpepper 2006; Grichar et al. 2004; Price et al. 2008; Scroggs et al. 2007). Everman et al. (2009) and Scroggs et al. (2007) reported increased weed control with the addition of PRE soil-residual herbicides in weed control programs for glufosinate- and glyphosate-resistant cotton. Using soil-residual herbicides not only can eliminate or reduce early-season competition from weeds to help secure maximum crop yield, using them also allows grower flexibility in timing of POST applications if needed (Ellis and Griffin 2002). Soil-residual herbicides are commonly used now to control glyphosate-resistant weeds in various crops.

In susceptible plants, inhibition of protoporphyrinogen oxidase (PPO), an enzyme in the chlorophyll biosynthesis pathway, causes accumulation of porphyrins and increases peroxidation of membrane lipids, which leads to irreversible damage of the membrane function and structure (Duke et al. 1991; Grossman et al. 2010, 2011). Increasing infestations of glyphosateand acetolactate synthase (ALS)-resistant Palmer amaranth (Amaranthus palmeri S. Watson) in cotton has forced producers to use herbicides with alternative modes of action in their management systems (Sosnoskie and Culpepper 2014). Of particular interest is the increased use of PPO herbicides and glufosinate for the management of glyphosate-resistant Palmer amaranth. Palmer amaranth can be controlled in systems using glufosinate and PPO herbicides such as 
flumioxazin and fomesafen (Everman et al. 2009; Gardner et al. 2006; Whitaker et al. 2011a, 2011b). Of the PPO herbicides typically applied PRE or preplant (PP), both fomesafen and flumioxazin have been two of the most effective, providing $74 \%$ to $100 \%$ Palmer amaranth control $20 \mathrm{~d}$ after planting (DAP) (Whitaker et al. 2011b). The use of PPO-inhibiting herbicides across all crops has increased 25\% (by value) globally since 2009 (Phillips McDougall 2014). The increase in use has been in response to the occurrence of glyphosate-resistant weeds in the United States, especially Amaranthus species.

Trifludimoxazin [1,5-dimethyl-6-sulfanylidene-3-(2,2,7-trifluoro3-oxo-4-prop-2-ynyl-1,4-benzoxazin-6-yl)-1,3,5-triazinane-2,4-dione] is the first PPO-inhibiting herbicide containing a triazinone heterocycle (Armel et al. 2017), has a water solubility of $1.78 \mathrm{mg} \mathrm{L}^{-1}$, is a nonionic molecule, and has a soil adsorption coefficient (Koc) of 315-692 $\mathrm{mL} \mathrm{g}^{-1}$ (Table 1) (APVMA 2020). Trifludimoxazin is active when applied PRE or POST on broadleaf weeds, including known PPO target-based resistant Amaranthus biotypes possessing the $\delta$ glycine deletion or R128 substitution mutation, which are not controlled by currently registered PPO inhibitors (Armel et al. 2017).

Flumioxazin is a dicarboxamide herbicide developed by Valent (Senseman 2007), has a water solubility of $1.79 \mathrm{mg} \mathrm{L}^{-1}$ with no apparent $\mathrm{pH}$ effect on water solubility, is a nonionic molecule, and has a Koc of $557 \mathrm{~mL} \mathrm{~g}^{-1}$ (Table 1) (Mueller et al. 2014). Flumioxazin absorption to soil was highly correlated with organic matter, although it can become readily available in soil solution with an increase in soil water content (Ferrell et al. 2005). Flumioxazin is used in a wide range of crops, including soybean [Glycine $\max$ (L.) Merr] and cotton (Anonymous 2016).

Saflufenacil is a pyrimidinedione herbicide developed by BASF (Grossman et al. 2010). It has a water solubility of $210 \mathrm{mg} \mathrm{L}^{-1}$ at $\mathrm{pH}$ 7, which is directly related to $\mathrm{pH}$, is an ionic molecule, and has a Koc of $27 \mathrm{~mL} / \mathrm{g}$. Observed low sorption to soil and rapid dissipation suggest that saflufenacil would be readily available for degradation or plant uptake in the plant root zone (Table 1) (Mueller et al. 2014). The primary use of saflufenacil is PP burndown () in several crops including corn (Zea mays L.), soybean, and cotton (Anonymous 2017).

Soils differ across cropping regions and within fields in the United States, often resulting in herbicide-rate adjustment to obtain desired efficacy and crop safety. Many soil-residual herbicides have use restrictions or limitations related to soil properties that affect their behavior in the soil. The use of fomesafen, another PPO herbicide used in cotton, is limited to coarse-textured soils (eg, sandy loam, loamy sand, sandy clay loam) when applied PRE (Anonymous 2019)

West Texas cotton-production soils range in texture from fine to coarse, generally have low soil organic matter content and typically a high $\mathrm{pH}$. Evaluating application rates and timings of soil-applied residual herbicides as influenced by various soil parameters is critical for determining effective rates for weed control, crop selectivity, and recropping intervals (Gannon et al. 2014). As new soil-residual herbicides are developed for commercialization, testing under a wide range of soil conditions is required to determine their utility in weed management programs in West Texas. With the development and spread of glyphosate-resistant Palmer amaranth, multiple control options, including the use of soil-residual herbicides, will be needed to effectively manage this weed and other troublesome weeds in cotton. The objective of this research was to develop a use pattern for trifludimoxazin in West Texas cotton. Vertical mobility and greenhouse cotton tolerance trials were performed using three West Texas soils, and the results
Table 1. Attributes of various herbicides and details to experimental conductance.

\begin{tabular}{lcccc}
\hline Herbicide & $\begin{array}{c}\text { Water } \\
\text { solubility }\end{array}$ & $\begin{array}{c}\text { Adsorption } \\
\text { coefficient (Koc) }\end{array}$ & Ionic & 1× Field rate \\
\hline Flumioxazin & $\mathrm{mg} \mathrm{L}^{-1}$ & $\mathrm{~mL} \mathrm{~g}^{-1}$ & & $\mathrm{~g} \mathrm{ai} \mathrm{ha}^{-1}$ \\
Saflufenacil & 1.79 & 889 & No & 35.5 \\
Trifludimoxazin & 201 at pH 7 & 27 & Yes & 25.0 \\
\hline
\end{tabular}

were compared with two commercially used PPO herbicides in cotton.

\section{Materials and Methods}

\section{Bulk Soils}

Bulk samples were collected from the top $15 \mathrm{~cm}$ of the soil profile (Acuff loam [Cotton Center, TX; $33.56^{\circ} \mathrm{N}, 102.0^{\circ} \mathrm{W}$ ]; Olton loam [Halfway, TX; $34.10^{\circ} \mathrm{N}, 101.56^{\circ} \mathrm{W}$ ]; Amarillo loamy sand [Seagraves, TX; $32.58^{\circ} \mathrm{N}, 102.39^{\circ} \mathrm{W}$ ]). To prepare the soils, each was air dried at room temperature and passed through a $2-\mathrm{mm}$ sieve. Samples were sent to Midwest Laboratories, Inc., (Omaha, $\mathrm{NE}$ ) for soil-property analysis (Table 2).

\section{Herbicide Vertical Mobility}

Comparative vertical mobility of trifludimoxazin, saflufenacil, and flumioxazin was evaluated within each of the three West Texas soils using a bioassay soil-column technique (Nelson and Penner 2007). A polyvinyl chloride (PVC) soil column $15.24 \mathrm{~cm}$ tall by $7.62 \mathrm{~cm}$ diam was filled with $626.6 \mathrm{~cm}^{3}$ of each soil (Acuff, $755 \mathrm{~g}$; Amarillo, $845 \mathrm{~g}$; Olton, $741 \mathrm{~g}$ ). Soil was placed in each column, one-third of the total amount at a time, and hand-packed between fillings. After filling and packing, a 15-mm headspace remained at the top of each PVC soil column. The packed soil columns were irrigated with a rainfall simulator to bring each soil to field capacity (Acuff, $198 \mathrm{~mL}$; Amarillo, $125 \mathrm{~mL}$; Olton, $211 \mathrm{~mL}$ ). Columns were allowed to drain and dry for $48 \mathrm{~h}$.

Using a bulb pipette, $5 \mathrm{~mL}$ of stock herbicide solution providing the $1 \times$ field rate of each herbicide (Table 1 ) was applied to the surface of each soil column. Rates represent the current commercial use rate for flumioxazin and saflufenacil and the targeted use rate for trifludimoxazin (Table 1). After $2 \mathrm{~h}$, columns were placed in the rainfall simulator and $2.54 \mathrm{~cm}$ of rainfall $(116 \mathrm{~mL}$ of water applied to each soil column) was applied over $40 \mathrm{~min}$. Columns were set aside for $24 \mathrm{~h}$ to drain before being split vertically into two halves. Two rows of DeKalb DKL 52-41 Roundup Ready (Monsanto, St. Louis, MO) canola (Brassica napus L.) was seeded $\left(0.64 \mathrm{~cm}\right.$ deep; 1.0 teaspoon of seed column $\left.{ }^{-1}\right)$ lengthwise into the soil column as the herbicide-susceptible indicator species. Columns were placed in the greenhouse (constant temperature of $28 \mathrm{C}, 14 \mathrm{~h}$ day-length with supplemental lighting triggered when ambient light reached less than 2,000 watts $\mathrm{m}^{-2}$, constant $50 \%$ relative humidity) and watered twice daily. Vertical mobility from the soil surface, indicated by the depth at which the indicator species exhibited a visual response was measured 7 and $10 \mathrm{~d}$ after treatment (DAT).

\section{Greenhouse Cotton Tolerance}

Plastic pots, 10.16 by $10.16 \mathrm{~cm}$, were filled with each of the three West Texas soils. Pots were transferred to the greenhouse (same 
Table 2. Properties of soil samples $(0-15 \mathrm{~cm}$ deep) for each West Texas soil.

\begin{tabular}{|c|c|c|c|c|c|c|c|}
\hline Series & Tex ${ }^{a, b}$ & $\mathrm{OM}^{\mathrm{c}}$ & Sand $^{d}$ & Silt loam ${ }^{d}$ & Clay $^{d}$ & $\mathrm{CEC}^{\mathrm{e}}$ & $\mathrm{pH}^{\mathrm{f}}$ \\
\hline & & & & & & $\mathrm{cmol} \mathrm{kg}^{-1}$ & 1:1 \\
\hline Acuff & $\mathrm{L}$ & 1.5 & 45 & 43 & 12 & 22.1 & 8.3 \\
\hline Amarillo & LS & 0.3 & 86 & 6 & 8 & 8.7 & 8.2 \\
\hline Olton & $\mathrm{L}$ & 1.0 & 51 & 29 & 20 & 19.1 & 8.1 \\
\hline
\end{tabular}

aAbbreviations: C, clay; CEC, cation exchange capacity; L, loam; LS, loamy sand; OM, organic matter; Tex, soil texture.

${ }^{b}$ Soil textural classification.

'Organic matter was determined by a loss on ignition method (Dean 1974).

dParticle analysis was determined using the hydrometer method (Gee and Orr 2002).

${ }^{e} \mathrm{CEC}$ was determined using the summation of exchangeable cations procedure (Mehlich

1984).

${ }_{\mathrm{f}}^{\mathrm{pH}}$ was determined using a 1:1 soil-to-distilled water ratio (Peech 1965).

conditions as described in the vertical mobility study), fully watered, and allowed to drain to field capacity. A single Stoneville 4946 GlyTol $^{\star}$ LibertyLink $^{\star}$ Genuity $^{\star}$ Bollgard II ${ }^{\star}$ (Bayer Crop Science, Research Triangle Park, NC) cotton seed was planted at a depth of $2.54 \mathrm{~cm}$ in each pot immediately before PRE treatments and $14 \mathrm{~d}$ after application for the PP treatments. This depth is within the recommended planting depth of 0.6 to 3.8 $\mathrm{cm}$ to optimize emergence (Cotton Foundation 2020) and the current label restriction for flumioxazin used PP in strip-till/no-till cotton (Anonymous 2016). Each of the herbicides was applied using a spray chamber (TeeJet ${ }^{\oplus}$ XR $80015 ; 140 \mathrm{~L} \mathrm{ha}^{-1}, 275 \mathrm{kPa}$, $4.8 \mathrm{~km} \mathrm{~h}^{-1}$ ) using the $1 \times$ field rate shown in Table 1 . Pots were transferred to the greenhouse and allowed to dry for $2 \mathrm{~h}$ prior to receiving an overhead watering of $2.54 \mathrm{~cm}$ to activate the herbicide. Pots were watered twice daily for the duration of the experiment. Visual plant response was recorded at 14 and 28 DAP.

Aboveground cotton fresh weight was recorded 28 DAP by cutting each plant at the soil surface. Plants were placed in an oven dryer at $32 \mathrm{C}$ for $12 \mathrm{~h}$ and dry weights recorded. Dry weight as compared with the nontreated control (NTC) within each soil type was calculated for each plant.

\section{Statistical Analysis}

The herbicide vertical mobility experiment used a completely randomized design with three replications for each soil by herbicide combination and the experiment was conducted twice. The greenhouse cotton tolerance experiment was arranged in a completely randomized design with 3 three pots repetition ${ }^{-1}$ and 3 repetitions run $^{-1}$, and was conducted twice. Data were subjected to ANOVA and means separated by Fisher protected LSD at the 5\% level (SAS 2013).

\section{Results and Discussion}

\section{Herbicide Vertical Mobility}

Differences in herbicide vertical mobility were observed among herbicide by soil combinations. No differences were seen with observation time (7 DAT vs. $10 \mathrm{DAT}$ ); thus, only the $10 \mathrm{DAT}$ data are reported. All flumioxazin soil combinations had similar vertical mobility at 10 DAT (Table 3 ). Trifludimoxazin mobility at 10 DAT in the Acuff and Olton soils was similar to flumioxazin (range, $1.7-2.5 \mathrm{~cm}$ ), but trifludimoxazin exhibited $79 \%$ greater vertical mobility than flumioxazin in the Amarillo soil (Table 3). Vertical mobility of saflufenacil was greater than all other respective herbicide by soil combinations 10 DAT $(6.2-13.5 \mathrm{~cm})$ and was
Table 3. Vertical mobility of three protoporphyrinogen oxidase-inhibiting herbicides in three West Texas soils.

\begin{tabular}{llc}
\hline Herbicide (rate $g$ ai ha & Soil & $10 \mathrm{~d}_{\text {after treatment }}{ }^{\mathrm{a}}$ \\
\hline & & $-\mathrm{cm}-$ \\
Flumioxazin (35.5) & Acuff & $1.7 \mathrm{a}$ \\
& Amarillo & $2.8 \mathrm{a}$ \\
Saflufenacil (25.0) & Olton & $1.9 \mathrm{a}$ \\
& Acuff & $7.2 \mathrm{c}$ \\
Trifludimoxazin (25.0) & Amarillo & $13.5 \mathrm{~d}$ \\
& Olton & $6.2 \mathrm{bc}$ \\
& Acuff & $2.5 \mathrm{a}$ \\
& Amarillo & $5.0 \mathrm{~b}$ \\
& Olton & $2.5 \mathrm{a}$ \\
\hline
\end{tabular}

aMeans within a column followed by the same letter are not different according to Fisher protected LSD test at $\mathrm{P}=0.05$.

greatest in the Amarillo soil 10 DAT $(13.5 \mathrm{~cm})$ (Table 3). The Amarillo soil was the most coarse-textured soil (loamy sand) and contained the least amount of organic matter $(0.3 \%)$ of the three West Texas soils tested. These findings are consistent with previous studies that showed percent organic matter had the greatest impact on herbicide bioavailability (Parochetti 1973; Rahman and Matthews 1979; Sheets et al. 1962; Stevenson 1972; Weber et al. 1987).

\section{Greenhouse Cotton Tolerance}

At the PP application timing, trifludimoxazin and flumioxazin by soil combinations caused similar cotton response 14 and 28 DAP ( $0 \%$ to $13 \%)$ (Table 4$)$. The PP saflufenacil treatment caused more cotton response than all trifludimoxazin or flumioxazin PP by soil combinations except for the Amarillo soil 14 DAP, when all three herbicides produced similar cotton response (Table 4). All PRE herbicide by soil combination treatments caused greater levels of cotton response than the PP herbicide by soil combinations at 14 and 28 DAP, except for flumioxazin in the Olton soil $(7 \%$ and $8 \%$, respectively). Trifludimoxazin and saflufenacil PRE treatments had similar levels of cotton response across all soil combinations at 28 DAP (65\% to $79 \%)$ and were greater than any flumioxazin by soil PRE treatment ( $8 \%$ to $36 \%)$. The only PRE herbicide by soil treatment with similar cotton response to the PP herbicide by soil combinations at 28 DAP was flumioxazin in the Olton soil (8\%) (Table 4).

Cotton fresh-weight comparisons to the NTC (data not shown) were similar to the dry weight comparisons. Within each soil, cotton dry weight after the trifludimoxazin and flumioxazin PP treatments was similar to the NTC and ranged from $96 \%$ to $107 \%$ and $103 \%$ to $105 \%$, respectively (Table 5). This corresponds to the visual cotton response recorded at $28 \mathrm{DAP}$, which indicated that these treatments were similar (Table 4). Preplant saflufenacil cotton dry weight within each soil was less than the NTC and lower than trifludimoxazin and flumioxazin (Table 5). This also corresponded to the cotton response observed at 28 DAP (Table 4). Across soils, cotton dry weight after the trifludimoxazin and saflufenacil PRE treatments were similar and lower than the NTC (29\% to $37 \%$ and $27 \%$ to $47 \%$, respectively) (Table 5). Flumioxazin-induced cotton dry weight was similar to the NTC after the PRE treatments across all three West Texas soils (80\% to 105\%) (Table 5).

PRE herbicide treatments resulted in greater levels of cotton response than did the PP treatments within all soils. PRE treatments of trifludimoxazin and saflufenacil resulted in similar high 
Table 4. Cotton response from PRE and preplant applications of three protoporphyrinogen oxidase-inhibiting herbicides in three West Texas soils.

\begin{tabular}{|c|c|c|c|c|c|}
\hline \multirow[t]{2}{*}{ Herbicide (rate g ai ha ${ }^{-1}$ ) } & \multirow[t]{2}{*}{ Soil } & \multicolumn{2}{|c|}{$\begin{array}{l}\text { Cotton injury a } \\
14 \mathrm{DAP}^{\mathrm{a}, \mathrm{b}}\end{array}$} & \multicolumn{2}{|c|}{$\begin{array}{l}\text { Cotton injury } \\
\text { a } 28 \mathrm{DAP}^{\mathrm{b}}\end{array}$} \\
\hline & & PP & PRE & PP & PRE \\
\hline & & & & & \\
\hline \multirow[t]{3}{*}{ Flumioxazin (35.5) } & Acuff & $0 \mathrm{a}$ & $33 b$ & $0 \mathrm{a}$ & $28 \mathrm{~b}$ \\
\hline & Amarillo & $8 \mathrm{a}$ & $34 b$ & $0 \mathrm{a}$ & $36 \mathrm{~b}$ \\
\hline & Olton & $1 \mathrm{a}$ & $7 \mathrm{a}$ & $0 \mathrm{a}$ & $8 a$ \\
\hline \multirow[t]{3}{*}{ Saflufenacil (25.0) } & Acuff & $38 \mathrm{~b}$ & $48 \mathrm{~b}$ & 54 & $65 \mathrm{~cd}$ \\
\hline & Amarillo & $13 \mathrm{a}$ & $70 \mathrm{~cd}$ & 31 & $71 \mathrm{~cd}$ \\
\hline & Olton & $42 \mathrm{~b}$ & $61 \mathrm{c}$ & 55 & $79 \mathrm{~d}$ \\
\hline \multirow[t]{3}{*}{ Trifludimoxazin (25.0) } & Acuff & 5 a & $74 \mathrm{~cd}$ & $3 a$ & $79 \mathrm{~d}$ \\
\hline & Amarillo & $8 \mathrm{a}$ & $80 \mathrm{~d}$ & 5 a & $76 \mathrm{~d}$ \\
\hline & Olton & $13 \mathrm{a}$ & $77 \mathrm{~cd}$ & 7 a & $79 \mathrm{~d}$ \\
\hline
\end{tabular}

aAbbreviations: DAP, days after planting; PP, preplant.

${ }^{b}$ Means within a column followed by the same letter are not different according to Fisher protected LSD test at $\mathrm{P}=0.05$.

Table 5. Percentage of the nontreated control cotton dry weight from preplant and PRE applications of three protoporphyrinogen oxidase-inhibiting herbicides in three West Texas soils.

\begin{tabular}{llrr}
\hline Herbicide (rate $\mathrm{g} \mathrm{ai} \mathrm{ha}^{-1}$ ) & Soil & NTC & \\
& & & NTC PRE \\
\cline { 2 - 3 } Flumioxazin (35.5) & Acuff & $104 \mathrm{a}$ & $80 \mathrm{a}$ \\
& Amarillo & $105 \mathrm{a}$ & $94 \mathrm{a}$ \\
& Olton & $103 \mathrm{a}$ & $105 \mathrm{a}$ \\
Saflufenacil (25.0) & Acuff & $45 \mathrm{~b}$ & $47 \mathrm{~b}$ \\
& Amarillo & $57 \mathrm{~b}$ & $29 \mathrm{~b}$ \\
Trifludimoxazin (25.0) & Olton & $39 \mathrm{~b}$ & $27 \mathrm{~b}$ \\
& Acuff & $107 \mathrm{a}$ & $37 \mathrm{~b}$ \\
& Amarillo & $96 \mathrm{a}$ & $29 \mathrm{~b}$ \\
& Olton & $97 \mathrm{a}$ & $27 \mathrm{~b}$ \\
\hline
\end{tabular}

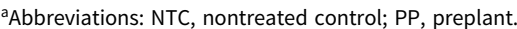

${ }^{\mathrm{b}}$ Means within a column followed by the same letter are not different according to Fisher protected LSD test at $\mathrm{P}=0.05$.

levels of cotton response across soils at 28 DAT (78\% and $72 \%$, respectively), which were greater than flumioxazin (24\%). Cotton dry weight as a percent of the NTC within each soil was similar for the flumioxazin PRE treatments. All PP treatments of trifludimoxazin and flumioxazin, when averaged across soils, had similar levels of cotton response to the NTC at 14 and 28 DAT. Cotton dry weight as a percent of the NTC within each soil was similar for all trifludimoxazin and flumioxazin PP treatments. All saflufenacil PP treatments resulted in greater cotton response and reduced dry weights when compared with the NTC.

Soil vertical mobility of saflufenacil does not offer the opportunity for selectivity based on placement for a PRE or $14 \mathrm{~d}$ PP applications in cotton. This supports the current label use restriction of $42 \mathrm{~d}$ PP before cotton planting (Anonymous 2017). For flumioxazin, planting cotton at a depth of $2 \mathrm{~cm}$ or deeper would create an opportunity for selectivity based on placement, at least in the Acuff and Olton soils, because the herbicide only moved to a depth of $1.7-1.9 \mathrm{~cm}$ in those soils. This work supports the results reported by Berger et al. (2012), indicating the current labelled PP application window (Anonymous 2016) of 14 to $21 \mathrm{~d}$ could be shortened with little crop response after flumioxazin PP. Along with a PP interval, placement selectivity with flumioxazin with planting depths of $2 \mathrm{~cm}$ or deeper might be achieved. To achieve selectivity in cotton with trifludimoxazin, a PP application window must be implemented. Selectivity based on placement will not be possible, because the vertical mobility of trifludimoxazin was $2.5 \mathrm{~cm}$ or greater in all three West Texas soils. To refine the use pattern for trifludimoxazin in cotton, more work is needed to define the PP application window and if a use-rate range can be created for soils with differing soil properties.

Acknowledgments. Appreciation is extended to BASF Corporation for providing laboratory and greenhouse facilities for this research. BASF and several authors on this paper are involved with obtaining registration and developing a use pattern for trifludimoxazin in cotton and various other crops. No conflicts of interest have been declared.

\section{References}

Anonymous (2016) Valor SX herbicide label. Valent U.S.A Corporation. www. cdms.net/Idat/Id3LL006.pdf. Accessed: February 28, 2020

Anonymous (2017) Sharpen herbicide label. BASF. www.cdms.net/Idat/ Id99E000.pdf. Accessed: February 28, 2020

Anonymous (2019) Reflex herbicide label. Syngenta Crop Protection LLC. http://www.cdms.net/ldat/ld6BJ037.pdf. Accessed: July 22, 2020

Armel GR, Hanzlik K, Witschel M, Hennigh DS, Bowe S, Simon A, Libel R, Mankin L (2017) Trifludimoxazin: a new PPO inhibitor that controls PPO resistant weed biotypes. Page 61 in Proceedings of the Weed Science Society of America. Arlington, VA; Weed Science Society of America

[APVMA] Australian Pesticides and Veterinary Medicines Authority. Public Release Summary: On the evaluation of the new active trifludimoxazin in the product Voraxor herbicide. APMVA product number 8645, April 2020. https://apvma.gov.au/sites/default/files/publication/65676-prs_on_trifludimoxazin_ in_the_product_voraxor_herbicide.pdf. Accessed: April 7, 2020

Berger S, Ferrell J, Brecke JB, Faircloth W, Rowland D (2012) Influence of flumioxazin application timing and rate on cotton emergence and yield. Weed Technol 26:622-626

Bond JA, Dodds DM, Eubank TW, Reynolds DB (2011) Herbicide programs for managing glyphosate- and ALS-resistant Palmer amaranth in Mississippi cotton. Information Sheet 1354. Starkville, MS: Mississippi Agricultural and Forestry Experiment Station. $2 \mathrm{p}$

Burke IC, Troxler SC, Askew SD, Wilcut JW, Smith WD (2005) Weed management systems in glyphosate-resistant cotton. Weed Technol 19:422-429

Clewis SB, Miller DK, Koger CH, Baughman TA, Price AJ, Porterfield D, Wilcut JW (2008) Weed management and crop response with glyphosate, S-metolachlor, trifloxysulfuron, prometryn and MSMA in glyphosate-resistant cotton. Weed Technol 22:160-167

Cotton Foundation. Integrated crop management. Establishing the crop. www. cotton.org/tech/ace/establishing-the-crop.cfm. Accessed: February 28, 2020

Culpepper AS (2006) Glyphosate-induced weed shifts. Weed Technol 20: 277-281

Dean WE (1974) Determination of carbonate and organic matter in calcareous sediments and sedimentary rocks by loss on ignition: comparison with other methods. J Sed Retrol 44:242-248

Duke SO, Lydon J, Becerril JM, Sherman TD, Lehnen LP Jr, Matsumoto H (1991) Protoporphyrinogen oxidase-inhibiting herbicides. Weed Sci 39:465-473

Ellis JM, Griffin JL (2002) Benefits of soil-applied herbicides in glyphosateresistant soybean (Glycine max). Weed Technol 16:541-547

Everman WJ, Clewis SB, York AC, Wilcut JW (2009) Weed control and yield with flumioxazin, fomesafen and $S$-metolachlor systems for glufosinateresistant cotton residual weed management. Weed Technol 23:391-397

Ferrell JA, Vencill WK, Xia K, Grey TL (2005) Sorption and desorption of flumioxazin to soil, clay minerals and ionic-exchange resin. Pest Manag Sci 61:40-46.

Gannon TW, Hixson AD, Keller KE, Weber JB, Knezevic SZ, Yelverton FH (2014) Soil properties influence saflufenacil phytotoxicity. Weed Sci 62:657-663

Gardner AP, York AC, Jordon DL, Monks DW (2006) Management of annual grasses and Amaranthus spp. in glufosinate-resistant cotton. J Cotton Sci 10:328-338 
Gee GW, Orr D (2002) Particle-size analysis. Pages 255-328 in Dane JH, Tropp GC, eds. Methods of Soil Analysis. Part 4. SSSA Book Series No. 5. Madison, WI: Soil Science Society of America

Grichar WJ, Besler BA, Brewer KD, Minton BW (2004) Using soil-applied herbicides in combination with glyphosate in glyphosate-resistant cotton herbicide program. Crop Prot 23:1007-1010

Grossmann K, Hutzler J, Caspar G, Kwiatkowski J, Brommer CL (2011) Saflufenacil (Kixor): biokinetic properties and mechanism of selectivity of a new protoporphyrinogen IX oxidase inhibiting herbicide. Weed Sci 59:290-298

Grossmann K, Niggeweg R, Christiansen N, Looser R, Ehrhardt T (2010) The herbicide saflufenacil (Kixor) is a new inhibitor of protoporphyrinogen IX oxidase activity. Weed Sci 58:1-9

Mehlich A (1984) Mehlich 3 soil test extractant: a modification of Mehlich 2 extractant. Comm Soil Sci Plant Anal 15:1409-1416

Mueller TC, Boswell BW, Mueller S, Steckel LE (2014) Dissipation of fomesafen, saflufenacil, sulfentrazone and flumioxazin from a Tennessee soil under field conditions. Weed Sci 62:664-671

Nelson EA, Penner D (2007) Leaching of isoxaflutole and the herbicide safeners R-29148 and Furilazole. Weed Technol 21:106-109

Norsworthy JK, Ward S, Shaw D, Llewellyn R, Nichols R, Webster TM, Bradley K, Fisvold G, Powles S, Burgos N, Witt W, Barrett M. (2012) Reducing the risks of herbicide resistance: best management practices and recommendations. Weed Sci. 60:31-62

Parochetti JV (1973) Soil organic matter effect on activity of acetamides, CDAA and atrazine. Weed Sci 21:157-160

Peech M (1965) Hydrogen-ion activity. Pages 914-925 in Black CA, ed. Methods of Soil Analysis, Part 2, Chemical and Microbiological Properties \#9. Madison, WI: American Society of Agronomy

Phillips McDougall (2014) AgriService Products Section. Midlothian, UK. 12 p
Price AJ, Koger CH, Wilcut JW, Miller D, Van Santen E (2008) Efficacy of residual and non-residual herbicides used in cotton production systems when applied with glyphosate, glufosinate and MSMA. Weed Technol 22:459-466

Rahman A, Matthews LJ (1979) Effect of soil organic matter on the phytotoxicity of thirteen s-triazine herbicides. Weed Sci 27:158-161

SAS Institute(2013) SAS/STAT User's Guide. Release 9.3. Cary, NC: SAS Institute

Scroggs DM, Miller DK, Griffin JL, Wilcut JW, Blouin DC, Stewart AM, Vidrine PR (2007) Effectiveness of preemergence herbicides and postemergence glyphosate programs in second-generation glyphosate-resistant cotton. Weed Technol 21:877-881

Senseman SA (2007) Flumioxazin. In: Herbicide Handbook. Lawrence, KS: Weed Science Society of America. Pp 202-203

Sheets TJ, Crafts AS, Drever HR (1962) Influence of soil properties on the phytotoxicities of the S-triazine herbicides. J Agric Food Chem 10: 458-462

Sosnoskie LM, Culpepper AS (2014) Glyphosate-resistant Palmer amaranth (Amaranthus palmeri) increases herbicide use, tillage and hand-weeding in Georgia cotton. Weed Sci 62:393-402

Stevenson FJ (1972) Organic matter reactions involving herbicides in soil. J Environ Qual 1:333-343

Weber JB, Tucker MR, Isaac RA (1987) Making herbicide rate recommendations based on soil tests. Weed Technol 1:41-45

Whitaker JR, York AC, Jordan DL, Culpepper AS (2011a) Weed management with glyphosate- and glufosinate-based systems in PHY 485 WRF cotton. Weed Technol 25:183-191

Whitaker JR, York AC, Jordon DL, Culpepper AS, Sosnoskie LM (2011b) Residual herbicides for Palmer amaranth control. J Cotton Sci 15:89-99 